\title{
PROBLEMATIKA PEMBELAJARAN MEMBACA DAN MENULIS PERMULAAN DI SEKOLAH DASAR
}

\author{
Oleh \\ Nyoman Suastika \\ Guru SDN 1 Bungkulan, Kabupaten Buleleng \\ nyomansuastika1966@gmail.com
}

\begin{abstract}
Language is a communication tool that is a symbolic system of sound produced by a human speech tool. Language as a means of communication can not only talk, but can be manifested by hand signals or other bodies that have their own rules. Language has a central role in the intellectual, social, and emotional development of students. This means every human being is subject to limitations in the language. The development of children's speaking skills in elementary schools will become the language for their effective and efficient communication. Learning to read in primary school is very important. This is caused by learning that can not only be utilized in improving the language skills of children, more than that, that is to improve students' ability in learning other subjects. The essence of writing skills is to increase the vocabulary insight for students, so that students are encouraged to think dynamic, critical, rational and able to live up to the conditions and goals of good and true teaching. However, on various matters relating to the process of reading and writing beginning in elementary school. This should not be allowed to happen continuously will cause an imbalance in the development of students' thinking ability. In addition to teachers, parents also play an important role in helping to solve problems by learning to read and write the beginning. Here the authors formulate some efforts to overcome this, namely: choosing reading materials, making the media as a song, choose innovative learning media, and motivate students by providing feedback.
\end{abstract}

Keywords: Language, Reading, Writing, Elementary School

\section{PENDAHULUAN}

Bahasa adalah alat komunikasi yang berupa sistem lambang bunyi yang dihasilkan oleh alat ucap manusia. Bahasa merupakan alat komunikasi baik lisan, gerakan maupun tulisan, yang mampu dimengerti orang lain dan mampu menjadi media dalam pertukaran pikiran, wawasan dan perasaan dalam kehidupan bermasyarakat sehari-hari. Bahasa sebagai alat komunikasi tidak hanya berupa bicara, namun dapat diwujudkan dengan tanda isyarat tangan atau anggota tubuh lainnya yang memiliki aturan sendiri

Bahasa memiliki peran sentral dalam perkembangan intelektual, sosial, dan emosional siswa. Ini berarti setiap manusia dituntut terampil dalam menggunakan bahasa. Pengembangan kemampuan berbahasa anak di sekolah dasar akan menjadikan bahasa sebagai alat komunikasi mereka yang efektif dan efisien. Kemampuan berbahasa anak akan berkembang seiring dengan perkembangan mental dan kognitif 
anak. Terdapat empat aspek kemampuan bahasa anak yaitu kemampuan menyimak, kemampuan berbicara, kemampuan menulis, dan kemampuan membaca. Kemampuan menyimak dan kemampuan berbicara merupakan kemampuan berbahasa lisan sedangkan kemampuan membaca dan kemampuan menulis merupakan kemampuan berbahasa tertulis.

Membaca merupakan salah satu keterampilan berbahasa yang diajarkan dalam mata pelajaran bahasa Indonesia di sekolah. Menurut Rahim (2011:1) membaca pada hakikatnya adalah suatu yang rumit yang melibatkan banyak hal, tidak sekedar melafalkan tulisan, tetapi juga melibatkan aktivitas visual, berfikir, psikolinguistik dan metakognitif. Dalam kehidupan sehari-hari peranan membaca tidak dapat dipungkiri lagi. Ada beberapa peranan yang dapat disumbangkan oleh kegiatan membaca antara lain: kegiatan membaca dapat membantu memecahkan masalah, dapat memperkuat suatu keyakinan atau kepercayaan pembaca, sebagai suatu pelatihan, memberi pengalaman estetis, meningkatkan prestasi, memperluas pengetahuan dan sebagainya.

Pembelajaran membaca di sekolah dasar dinilai sangat penting. Hal ini disebabkan oleh kenyataan bahwa pembelajaran membaca tidak hanya berperan dalam meningkatkan kemampuan berbahasa anak, tetapi lebih dari itu, yaitu untuk meningkatkan kemampuan siswa dalam mempelajari mata pelajaran yang lainnya. Namun kenyataanya pembelajaran membaca yang dilaksanakan di sekolah dasar masih belum memuaskan dan belum sesuai dengan harapan.
Hal tersebut, disebabkan pembelajaran membaca di sekolah dasar masih belum menitikberatkan pada pembentukan kebiasaan membaca pada siswa. Selain itu, pembelajaran membaca masih dianggap membosankan dan monoton. Kondisi ini ditengarai oleh belum maksimalnya pelaksanaan pembelajaran membaca di sekolah. Sebagian guru masih menerapkan prosedur pembelajaran membaca yang kurang tepat. Di sisi lain, pengembangan kemampuan metakognisi siswa melalui penguasaan berbagai macam strategi membaca masih diabaikan oleh guru. Kondisi tersebut dapat berdampak pada kemampuan membaca siswa yang dinilai masih cukup rendah

Pembelajaran membaca di SD dilaksanakan sesuai dengan pembedaan atas kelas-kelas awal dan kelas-kelas tinggi. Pelajaran membaca dan menulis di kelas-kelas awal disebut pelajaran membaca dan menulis permulaan, sedangkan di kelas-kelas tinggi disebut pelajaran membaca dan menulis lanjut. Membaca permulaan merupakan tahapan proses belajar membaca bagi siswa sekolah dasar kelas awal. Menurut Purwanto (1997: 25) disebut membaca permulaan jika dimaksud memberikan kecakapan kepada siswa untuk mengubah rangkaian huruf menjadi rangkaian bunyi bermakna dan melancarkan teknik membaca pada anak-anak. Siswa belajar untuk memperoleh kemampuan dan menguasai teknikteknik membaca dan menangkap isi bacaan dengan baik. Oleh karena itu guru perlu merancang pembelajaran membaca dengan baik sehingga mampu menumbuhkan kebisaan membaca sebagai suatu yang menyenangkan. 
Pada tingkatan membaca

permulaan, pembaca belum memiliki keterampilan kemampuan membaca yang sesungguhnya, tetapi masih dalam tahap belajar untuk memperoleh keterampilan / kemampuan membaca. Membaca pada tingkatan ini merupakan kegiatan belajar mengenal bahasa tulis. Melalui tulisan itulah siswa dituntut dapat menyuarakan lambang-lambang bunyi bahasa tersebut, untuk memperoleh kemampuan membaca diperlukan tiga syarat, yaitu kemampuan membunyikan (a) lambang-lambang tulis, (b) penguasaan kosakata untuk memberi arti, dan (c) memasukkan makna dalam kemahiran bahasa. Membaca permulaan merupakan suatu proses keterampilan dan kognitif. Proses keterampilan menunjuk pada pengenalan dan penguasaan lambang-lambang fonem, sedangkan proses kognitif menunjuk pada penggunaan lambang-lambang fonem yang sudah dikenal untuk memahami makna suatu kata atau kalimat (Huda dalam Sri Nuryati, 1997).

Pembelajaran membaca permulaan di SD mempunyai nilai yang strategis bagi pengembangan kepribadian dan kemampuan siswa. Pengembangan kepribadian dapat ditanamkan melalui materi teks bacaan (wacana, kalimat, kata, suku kata, huruf/bunyi bahasa) yang berisi pesan moral, nilai pendidikan, nilai sosial, nilai emosional-spiritual, dan berbagai pesan lainnya sebagai dasar pembentuk kepribadian yang baik pada siswa. Demikian pula dengan pengembangan kemampuan juga dapat diajarkan secara terpadu melalui materi teks bacaan yang berisi berbagai pengetahuan dan pengalaman baru yang pada akhirnya dapat berimplikasi pada pengembangan kemampuan siswa.

Kegiatan membaca permulaan tidak dapat dipisahkan dengan kegiatan menulis permulaan. Artinya, kedua macam keterampilan berbahasa tersebut dapat dilatihkan secara bersamaan. Ketika siswa belajar membaca, siswa juga belajar mengenal tulisan yakni berupa hurufsuku kata-kata-kalimat yang dibaca. Setelah belajar membaca satuan unit bahasa tersebut, siswa perlu belajar bagaimana menuliskannya. Demikian pula sebaliknya, ketika siswa belajar menulis huruf-suku kata-kata-kalimat, siswa juga belajar bagaimana cara membaca satuan unit bahasa tersebut. Hampir sama dengan pendekatan Whole Language yang menekankan kegiatan membaca dan menulis dimulai dari bentuk yang utuh dan tak terpisahkan (Musfiroh, 2009: 59)

Menulis adalah melahirkan pikiran atau gagasan (seperti mengarang,membuat surat) dengan tulisan. Menurut pengertian ini menulis merupakan hasil, yaitu melahirkan pikiran dalam perasaan kedalam tulisan. Setiap tulisan harus mengandung makna sesuai dengan pikiran, perasaan, ide, dan emosi penulis yang disampaikan kepada pembaca untuk dipahami tepat seperti yang dimaksud penulis. Dari beberapa pengertian menulis di atas dapat disimpulkan bahwa menulis adalah suatu proses berpikir yang teratur dalam mengungkapkan gagasan, pikiran dan perasaan dalam bentuk tulisan sehingga mudah dipahami pembaca. Sebuah tulisan dikatakan baik apabila memiliki ciriciri, antara lain bermakna, jelas, bulat dan utuh, ekonomis, dan memenuhi kaidah gramatika. Untuk 
dapat menghasilkan tulisan yang baik tersebut diperlukan kemampuan menulis yang baik pula.

Hakikat dari kemampuan menulis adalah untuk menambah wawasan perbendaharaan kata bagi siswa, sehingga siswa terdorong untuk berpikir dinamis, kritis, rasional serta dapat menghayati sesuai dengan kondisi dan tujuan pengajaran menulis yang baik dan benar. Kemampuan menulis adalah kemampuan seseorang untuk menuangkan buah pikiran, ide, gagasan, dengan mempergunakan rangkaian bahasa tulis yang baik dan benar. Kemampuan menulis merupakan salah satu kunci keberhasilan siswa dalam meraih kemajuan. Ahli ilmu pengetahuan dan teknologi tidak mungkin didapat tanpa melalui menulis. Budaya menulis perlu ditumbuhkembangkan sejak dini bukan hanya ketika anak memasuki usia sekolah.

Menulis merupakan kegiatan yang sifatnya berkelanjutan sehingga pembelajarannya pun perlu dilakukan secara berkesinambungan sejak di sekolah dasar. Hal ini didasarkan pada pemikiran bahwa menulis merupakan kemampuan dasar sebagai bekal belajar menulis di jenjang selanjutnya dan sebagai modal utama bagi setiap individu yang ingin mengembangkan kemampuannya secara optimal. Memiliki kemampuan menulis yang memadai, akan memudahkan siswa dalam menggali informasi dari berbagai sumber tertulis. Kemampuan menulis tidak diperoleh secara alamiah, melainkan melalui proses pembelajaran yang sebagian merupakan tanggung jawab guru. Dalam hal ini, guru dituntut dapat membantu dalam mengembangkan kemampuan menulis siswa. Oleh karena itu, kemampuan menulis di sekolah dasar merupakan kemampuan yang sangat penting dimiliki oleh setiap siswa karena keberhasilan siswa dalam menguasai berbagai teknik menulis memiliki konstribusi yang sangat besar terhadap perkembangan kemampuan yang lain.

Namun, pada kenyataannya terdapat berbagai macam permasalahan terkait dengan proses membaca dan menulis permulaan di sekolah dasar. Hal ini tidak boleh dibiarkan terjadi terus-menerus dikarenakan akan menyebabkan ketidakseimbangan perkembangan kemampuan berfikir siswa. Diperlukan berbagai upaya untuk mengatasi permasalahan tersebut. Berkaca dari hal tersebut, maka penting untuk dibahas terkait problematika pembelajaran membaca dan menulis permulaan di sekolah dasar dan upaya untuk mengatasinya.

\section{II.PEMBAHASAN}

\section{Problematika Membaca Dan Menulis Di Sekolah Dasar}

Kemampuan membaca dan menulis yang diperoleh siswa sekolah dasar akan menjadi dasar pembelajaran membaca dan menulis di kelas berikutnya. Sebagai kemampuan yang mendasari kemampuan berikutnya, kemampuan membaca dan menulis permulaan benar-benar memerlukan perhatian khusus dari guru, jika dasar itu tidak kuat, maka pada tahap membaca dan menulis lanjut siswa akan mengalami kesulitan untuk dapat memiliki kemampuan membaca dan menulis yang memadai. Siswa yang tidak mampu membaca dan menulis dengan baik akan mengalami kesulitan dalam 
mengikuti kegiatan pembelajaran pada semua mata pelajaran. Selain itu, siswa juga akan mengalami kesulitan menangkap dan memahami informasi yang disajikan dalam berbagai buku pelajaran. Hal ini akan berdampak pada kemajuan belajarnya, sehingga menjadi lamban jika dibandingkan dengan teman yang lainnya.

Kebisaaan dan kegemaran membaca dan menulis perlu ditumbuhkan sejak dini. Dalam rangka menumbuhkan kebisaaan dan kegemaran membaca dan menulis pada suatu masyarakat perlu dimulai secara bertahap. Dalam mata pelajaran Bahasa Indonesia di SD, kegiatan yang berkaitan dengan masalah tersebut terwadahi dalam pembelajaran membaca dan menulis permulaan, khususnya terdapat pada jenjang kelas 1 atau kelas 2 SD. Dalam kondisi normal, pelaksanaan pembelajaran membaca dan menulis permulaan tersebut akan berjalan lancar, artinya siswa dengan mudah memahami apa yang mereka pelajari dalam kegiatan membaca. Namun, tidak jarang ditemui berbagai permasalahan dalam pembelajaran membaca permulaan. Sebagian siswa telah lancar dan tidak mengalami hambatan dalam belajar membaca tetapi sebagian lainnya belum bahkan tidak dapat atau tidak mampu membaca. Berikut ini akan dijabarkan beberapa problematika membaca dan menulis permulaan yang penulis temui di lapangan.

a. Problematika Pembelajaran

Membaca Permulaan di Sekolah Dasar

Berdasarkan hasil wawancara yang penulis lakukan pada guru kelas II di sebuah sekolah negeri dan swasta di Buleleng, ditemukan sebuah permasalahan dalam pembelajaran membaca permulaan yaitu ada seorang siswa laki-laki yang belum fasih membaca kata dan kalimat, terkadang guru harus berulang-ulang kali menyuruh si anak untuk membaca namun hal ini tak berdampak sedikitpun bagi si anak. Si anak akan tetap diam dan tidak mau menggubris perintah dari gurunya. Hal ini memunculkan kekesalan dari siswa lain, lalu berdampak pada timbulnya cemoohan dari siswa lainnya. Si anak pun kurang mampu menghafal huruf A sampai dengan $\mathrm{Z}$.

b. Problematika Pembelajaran Menulis Permulaan di Sekolah Dasar

Berdasarkan hasil wawancara penulis lakukan dengan guru kelas II, ditemukan sebuah permasalahan dalam pembelajaran menulis permulaan yaitu seorang siswa lakilaki saat ditugaskan untuk menulis kata yang disebutkan oleh gurunya, hasil tulisan si anak ini tidak memiliki bunyi sama sekali, menurut pengakuan gurunya, si anak hafal macam huruf dari A sampai $\mathrm{Z}$. Namun berbeda halnya ketika guru menugaskan si anak untuk menyalin kata yang ada pada buku paket ataupun LKS, tulisan si anak ini mampu diartikan oleh gurunya. Selain itu, si anak memiliki daya ingat yang rendah dan tingkah lakunya mencerminkan siswa yang kurang disiplin karena suka mengganggu temannya.

\section{Upaya Mengatasi Problematika Membaca Dan Menulis}

Problematika yang ditemui dalam pembelajaran membaca dan menulis permulaan bukanlah sekedar problematika yang bisa dianggap 
remeh, namun ini akan menjadi sangat berdampak apabila dibiarkan terus-menerus. Oleh karena itu, guru kelas rendah haruslah berusaha dengan sungguh-sungguh agar ia dapat memberikan dasar kemampuan memadai dalam pelaksanaan pembelajaran yang baik. Menyikapi hal tersebut di atas, sebagai seorang guru tentunya memiliki tugas untuk mempersiapkan siswa agar termotivasi dalam meningkatkan kemampuan membaca dan menulis serta pemahaman terhadap apa yang dibaca dan ditulisnya. Selain guru, orang tua juga berperan penting dalam membantu mengatasi permasalahan berkaitan dengan pembelajaran membaca dan menulis permulaan. Berikut ini penulis merumuskan beberapa upaya untuk mengatasi hal tersebut, diantaranya:

a. Memilih bahan bacaan

Memilih materi bacaan merupakan salah satu tugas yang harus dilakukan guru. Materi bacaan yang memiliki daya tarik bagi siswa akan memotivasi siswa membaca teks dengan sungguh-sungguh. Selain itu bahan bacaan juga harus menarik secara visual mulai dari menampilkan gambar yang bervariasi dan dengan warna yang menarik pula.

b. Menjadikan huruf sebagai bahan nyanyian

Bagi siswa yang belum mampu mengenal huruf baik dalam membaca ataupun menulis, guru bisa membuatkan nyanyian sederhana namun menarik yang berisikan huruf-huruf agar si anak termotivasi untuk menghafal huruf-huruf.

c. Memilih Media Pembelajaran yang Inovatif
Penggunaan media pembelajaran sebagai penunjang dalam pembelajaran sangatlah penting. Dalam hal ini penggunaan media inovatif seperti Buklet Edukatif Tematik (BET) sangat berpengaruh terhadap kemampuan menulis siswa kelas rendah sesuai dengan penelitian yang dilakukan oleh Ni Luh Putu Agetania pada tahun 2014 dalam tesisnya yang berjudul Pengaruh Pendekatan Pembelajaran Kontekstual Berbantuan BET (Buklet Edukatif Tematik) dan Motivasi Belajar Terhadap Kemampuan Menulis Siswa Kelas II SD di Gugus V Kecamatan Sukasada. Penelitiannya membuktikan bahwa penggunaan media BET berpengaruh terhadap kemampuan menulis siswa kelas II SD.

d. Memilih Model Pembelajaran yang Inovatif dan Bervariatif Penerapan model-model pembelajaran yang inovatif dan bervariatif sangat membantu guru dalam berupaya mengatasi permasalahan yang berkaitan dengan membaca dan menulis permulaan diantaranya model pembelajaran Example Non Example, dan model pembelajaran Cooperative Integrated Reading And Composition (CIRC).

e. Program Bimbingan bagi

Orangtua

Menurut Mercer (dalam Abdurrahman: 2012) untuk mengatasi permasalahan yang berkaitan dengan pembelajaran membaca dan menulis permulaan yaitu dengan menggunakan pendekatan informasional. Pendekatan ini menekankan pada 
penyediaan pengetahuan bagi orangtua tentang kesulitan belajar. Misalnya dengan menyelenggarakan suatu rangkaian pertemuan bagi orangtua dan kepada mereka diberikan informasi dan latihan untuk membantu kesulitan tersebut.

f. Memotivasi Siswa dengan Memberikan Umpan Balik

Cara yang penting untuk membantu siswa tetap termotivasi dalam kelas ialah selalu memberitahu tentang kemajuan belajarnya. Oleh sebab itu, guru hendaknya memberi umpan balik sesegera mungkin ketika siswa sedang bekerja dan sesudah siswa melengkapi setiap tugas.

\section{III.SIMPULAN}

Problematika yang berkaitan dengan pembelajaran membaca permulaan sesuai dengan hasil wawancara penulis dengan guru kelas 2 yaitu ditemukannya siswa yang belum fasih membaca kata dan kalimat, terkadang guru harus berulang-ulang kali menyuruh si anak untuk membaca namun hal ini tak berdampak sedikitpun bagi si anak. Si anak akan tetap diam dan tidak mau menggubris perintah dari gurunya. Hal ini memunculkan kekesalan dari siswa lain, lalu berdampak pada timbulnya cemoohan dari siswa lainnya. Si anak pun kurang mampu menghafal huruf A sampai dengan $\mathrm{Z}$.

Problematika yang berkaitan dengan pembelajaran menulis permulaan sesuai dengan hasil wawancara penulis dengan guru kelas 2 yaitu ditemukannya siswa laki-laki yang pada saat ditugaskan untuk menulis kata yang disebutkan oleh gurunya, hasil tulisan si anak ini tidak memiliki bunyi sama sekali, menurut pengakuan gurunya si anak hafal macam huruf dari A sampai $\mathrm{Z}$. Namun berbeda halnya ketika guru menugaskan si anak untuk menyalin kata yang ada pada buku paket ataupun LKS, tulisan si anak ini mampu diartikan oleh gurunya. Selain itu, si anak memiliki daya ingat yang rendah dan tingkah lakunya mencerminkan siswa yang kurang disiplin karena suka mengganggu temannya.

Upaya untuk mengatasi problematika membaca dan menulis permulaan di sekolah dasar diantarannya adalah 1) memilih bahan bacaan yang memiliki daya tarik bagi siswa dan menarik secara visual mulai dari menampilkan gambar yang bervariasi dan dengan warna yang menarik pula, 2) menjadikan huruf sebagai bahan nyanyian, bagi siswa yang belum mampu mengenal huruf baik dalam membaca ataupun menulis, guru bisa membuatkan nyanyian sederhana namun menarik yang berisikan huruf-huruf agar si anak termotivasi untuk menghafal huruf-huruf, 3) memilih media pembelajaran yang inovatif seperti penggunaan media inovatif seperti Buklet Edukatif Tematik (BET) sangat berpengaruh terhadap kemampuan menulis siswa kelas, 4) memilih model pembelajaran yang inovatif dan bervariatif seperti contoh model pembelajaran example non example dan model pembelajaran Cooperative Integrated Reading And Composition (CIRC), 5) program bimbingan bagi orangtua yang menekankan pada penyediaan pengetahuan bagi orangtua tentang kesulitan belajar. Misalnya dengan menyelenggarakan 
http://ejournal.ihdn.ac.id/index.php/AW

suatu rangkaian pertemuan bagi orangtua dan kepada mereka diberikan informasi dan latihan untuk membantu kesulitan tersebut, dan 6) memotivasi siswa dengan memberikan umpan balik, ini merupakan cara yang penting untuk membantu siswa tetap termotivasi dalam kelas yaitu selalu memberitahu tentang kemajuan belajarnya. Oleh sebab itu, guru hendaknya memberi umpan balik sesegera mungkin ketika siswa sedang bekerja dan sesudah siswa melengkapi setiap tugas.

\section{DAFTAR PUSTAKA}

Abdurrahman, Mulyono. 2012. Anak Berkesulitan Belajar: Teori, Diagnosis dan Remediasinya. Jakarta: Rineka Cipta

Agetanian, Ni Luh Putu. 2014. Pengaruh Pendekatan Pembelajaran Kontekstual Berbantuan BET (Buklet Edukatif Tematik) dan Motivasi Belajar Terhadap Kemampuan Menulis Siswa Kelas II SD di Gugus V Kecamatan Sukasada. Tesis. Singaraja: Program Pascasarjana Universitas Pendidikan Ganesha

Huda, Akhmad. 2009. Pembelajaran Membaca Permulaan Dengan Pendekatan Pengalaman Berbahasa Di Kelas Awal Sekolah Dasar. Tersedia pada http://hudaita.blogspot.co.id /2009/01/pembelajaranmembaca-permulaandengan. html (diakses tanggal 20 Januari 2018)

Langi, Andi, dkk. 2011. Peningkatan Kemampuan Membaca Dan Menulis Dengan
Menggunakan Kartu Huruf di Kelas I SDN 2 Wombo. Jurnal Kreatif Tadulako (Online) Vol. 4 No. 8.

Musfiroh, Tadkiroatun. 2009. Menumbuhkembangkan Baca-Tulis Anak Usia Dini. Jakarta: Grasindo

Priyanto, Andi. 2012. Diagnosis Kesulitan Membaca Permulaan Siswa SD/MI Melalui Analisis Reading Readiness. Tersedia pada http://www.kompasiana.co m/andi-priyanto/ (diakses tanggal 20 Januari 2018)

Purwanto, Ngalim, dkk. 1997. Metodologi Pengajaran Bahasa Indonesia di Sekolah Dasar. Jakarta: Rosda Jayaputra

Rahim, Farida. 2011. Pengajaran

Membaca di Sekolah Dasar. Jakarta:

Bumi Aksara 